Cahiers d'études africaines

224|2016

Varia

Witchcraft and Violence in Ghana

An Assessment of Contemporary Mediation Efforts

Shelagh Roxburgh

CpenEdition

Journals

Édition électronique

URL : http://journals.openedition.org/etudesafricaines/18387

DOI : 10.4000/etudesafricaines. 18387

ISSN : $1777-5353$

Éditeur

Éditions de l'EHESS

Édition imprimée

Date de publication : 31 décembre 2016

Pagination : 891-914

ISSN : 0008-0055

Référence électronique

Shelagh Roxburgh, «Witchcraft and Violence in Ghana », Cahiers d'études africaines [En ligne], 224 |

2016, mis en ligne le 01 janvier 2016, consulté le 02 janvier 2020. URL : http://

journals.openedition.org/etudesafricaines/18387 ; DOI : 10.4000/etudesafricaines.18387

(C) Cahiers d'Études africaines 


\title{
Witchcraft and Violence in Ghana
}

\author{
An Assessment of Contemporary Mediation Efforts*
}

In the greater majority of the world, the threat of witchcraft is a daily reality, where people live within a state of spiritual insecurity, vulnerable to psychic attack from those around them (Ashforth 2005). For those who live outside of the reality of witchcraft, this very real and contemporary phenomenon is most visible in news reports of various forms of witchcraft-related violence. Though such violence is often sensationalized in media and presented in terms and language which persuades us to view these acts as shocking or appalling, for those who live amongst witches, "mob justice" as it is called in Ghana, is often viewed as the last defence against a world which is increasingly uncontrolled and uncontrollable.

An initial aim of this research project was to problematize the correlation made between witchcraft belief and violence and to investigate whether these two concepts are mutually constitutive. I began with the question: how can witchcraft-related violence be assessed in African contexts? From this first question I hoped to investigate the potential for mediating witchcraft-related violence. Unfortunately, as with every other aspect of the research, the complex and amorphous reality of witchcraft confounds any easy conclusion. Witches are driven to cause harm and do violence, therefore as long as they exist, violence will be bound to them. Yet, in many societies, there have been means to for mediating the threat of witchcraft attack which are non-violent, though some have been abandoned and others may prove to be irretrievable. Despite this, it remains one of the main focuses of this work: to address the problem of witchcraft-related violence in an effort to assess opportunities for addressing and mitigating spiritual insecurity towards reducing instances of witchcraft violence of all kinds.

As a political scientist, the second question that came to mind, was how witchcraft might be understood in terms of the political. Part of my reasoning behind this question was my interest and intent in taking the challenges put forth by Adam Ashforth (2005) and Dirk Kohnert (2007) seriously.

This article is an abridged version of my Ph.D. dissertation (ROXBURGH 2014). This work was carried out with the aid of a grant from the International Development Research Centre, Ottawa, Canada, <www.idrc.ca>. 
These authors have both persuasively argued the need to understand witchcraft-related violence in respect to the political landscape of African states. Though this call to duty is reinterpreted through an anarchist framework, looking at the politics of the individual within society, and vis-à-vis the state, it nevertheless aims to make a contribution towards developing a more complex and hopefully reflexive political analysis of witchcraft-related violence in sub-Saharan Africa.

In this approach, witchcraft is investigated as a fundamentally nonWestern concept of power, which translates into a unique conception of the political, including the nature of morality, justice, the state and society. Overall, this investigation has led to me to conclude that the Western construction of witchcraft-related violence in Africa may be best understood as a continuation of the colonizing mission which sought to alter African realities. In this case, the Western perception of reality, dominated by modernity, the liberal state and capitalism, is in conflict for hegemonic status with the pervasive and elusive reality of witchcraft. Much as these paradigms continue to attempt to alter reality around the world, including the West, where plurality of thought and alternative perceptions of reality continue to exist and are also marginalized by liberal and state discourse. In terms of witchcraft, this focus reveals a discursive point of conflict where what is at stake is the most essential ability of Africans to imagine and perceive their own world.

These conclusions reflect the analysis conducted of four main actors efforts to intervene in and address witchcraft-related violence. Over the course of two and half months research in Ghana in 2012, the state, NGOs, religious organizations and traditional authorities were assessed in their capacity to respond to the spiritual insecurity and violence associated with witchcraft. From the findings of twenty-five semi-structured interviews and two months of informal discussion with individuals in Accra, Tamale and Gambaga, I argue that of these actors, the state, NGOs and religious organizations are all unsuccessful in addressing witchcraft-related violence because they are made intolerant to the complexity of the problem by their own modern logic and embedded imperatives to conform the world to their version of reality. Traditional authorities, in my view, present the most potential for mediating and reducing witchcraft-related violence, however, these actors are limited by the modern institution of the state and further diminished by the modernist and individualizing discourses of NGOs and the most prominent religious organizations (Adjaye \& Misawa 2006; Atiemo 2006; Dzivenu 2008; Labranche 2002; Meyer 1998; Porter 2003). As a consequence of this, I argue that there is no simple solution to witchcraft-related violence. 


\section{Witchcraft as Reality}

Witchcraft is, above all else, a marginalized reality (Roxburgh 2014) ${ }^{1}$. In the works of Horkheimer and Adorno (2002), modernity and myth are counterpoised as dialectical forces, one speaking to reason and rationality, the other speaking to something more primal and unconscious, yet essential to our being-meaning. As a product of the European experience of enlightenment, modernity continues to reflect its foundation today, advancing the combined ideas and ideals of science, the state and capitalism. In essence, the modern world provides an order, a unified and universalizing conception of a singular, objective reality that can be known and accessed, and therefore controlled. As this modern reality advances, expanding across and penetrating deeper into our societies, lives and imaginations, its logic seeks to eliminate alternative conceptions of reality, forcing them to the margins of human discourse and experience. However, as argued by Horkheimer and Adorno, these alternative realities may be essential as they provide greater meaning and insight than modernity can offer.

Like some other areas of human experience and reality, such as aliens, ufos and cryptozoology, witchcraft is often considered as a "non-object" in its relation to sciences and the state, "something that is not just unidentified but unseen and thus ignored" (Wendt \& Duvall 2008: 610). In their article "Sovereignty and the Ufo", Wendt and Duvall attempt to unpack the taboo of ufos, and in so doing theorize an "epistemology of ignorance" in the words of Nancy Tuana, or "the production of (un)knowledge" in their own words (ibid.: 611). In this way, the exclusion and erasure of ufos, or witchcraft, from scientific and state discourses which invert the conceptual devices of rationality or power demonstrates an effort to critique the assumptions underlying this omission: that dissenting thought does not exist. Though the exclusion of witchcraft from political analyses is itself problematic, the inclusion of witchcraft also presents a number of conundrums.

Though witchcraft is not a uniquely African reality, the disproportionate attention given to African witchcraft phenomenon in Western academia may be seen as demonstrative of the imagined reality of this region in the West. In his work, P. Chabal (2009: 117) addresses this motivations underlying this anomaly, asking whether "questions that are more acute about Africa than about other areas" are so posed "not because Africa is effectively different but because we tend to approach it more differently". An example of the West's willingness to overlook marginalized realities in its own backyard includes the neglect that Ufology or conspiracy communities face in

1. Marginalized reality is a concept that I have developed in my dissertation in order to describe an epistemological system or experience of reality that is actively suppressed by modern thought. In this context, marginalized realities present a direct challenge to the authority of the dominant notion of reality advanced by modernity and complicate the consolidation of a coherent and unified order across the global imagination. 
academia and in political science in particular. Aside from a few keys studies, such as Jodi Dean's (1998) text Aliens in America, and the more recent compilation by Harry G. West and Todd Sanders (2003), Transparency and Conspiracy, there has been insufficient investigation into the potential the political implications of these marginalized realities.

This upsetting and upending of the Western political understanding of witchcraft as an irrational curio at best or a dangerous and backward threat to modernity at worst is essential to this work. The framing of witchcraft as a universal norm allows for the comparative framing of the Western modernizing project to be understood as it is seen here: a minority vision of the world (seen and unseen, and therefore non-existent) as it should be, seeking hegemony and domination over all other realities, which struggle in response to refute, mediate or selectively allow aspects of this project while managing undeniable social, political and economic changes in the visible world around them.

\section{Understanding Witchcraft}

In my field research, I did not present my working definition of witchcraft to interviewees or informants. Instead, the first question posed to each individual was for an explanation of their understanding of witchcraft. Though respondents varied in the wording of their explanations or descriptions, the common theme of causing harm was present in every definition of witchcraft. Though some viewed witchcraft with ambiguity, stating that supernatural power could be used for good too, these views were in the minority and in one group discussion led to an argument which ended with one respondent leaving in anger. In a particularly evocative description, one traditional healer ${ }^{2}$ pointed to his doorway where wind was blowing a long curtain in waves; witchcraft, he said, is what moves the curtain.

Witchcraft-related violence was frequently defined by respondents as verbal or physical attacks against women and men who have been accused of witchcraft. However, some respondents also defined witchcraft-related violence as the act of attacking another through supernatural means. Individuals who live among witches, in interviews and in discussion, therefore present a dilemma in defining violence: What is violent and what is necessary and just retribution or protection? Acts that may seem to be violent to those outside the logic of witchcraft may be preventive or protective in nature.

As well, violence was defined by some respondents in Ghana as being relevant only between human beings, which witches are not. The question can be extended to various forms of violence, including ritual murder, exorcisms and deliverance healing, witch cleansing and ordeals. In some instances, ritual murder was not seen a violent, but rather benign or beneficial,

2. Ghana, Traditional Authority, 17/09/2012. 
as it is assumed that the intention is not to cause the individual who is sacrificed harm, but to ensure productivity, where wealth generated by the act will benefit others' in the long run. In the case of ordeals, accused individuals may undergo torturous rituals in order to cleanse themselves of witchcraft power or of the stain of witchcraft accusation in order to reduce their own and others insecurity. Though many ordeals involve pain, the exaction of this is not seen as violent as it is applied first to a witch who after surviving the ordeals may again be considered part of human society.

A common word used by respondents in Ghana is the term "spiritual". In some cases, witches were referred to as spirits, having lost their status of human being in the process of accepting or allowing a nefarious spirit to enter them. This spirit, or power, is often seen as being integral to human existence, something that has always been and is always "with us". On the other hand, spiritual is also used to refer to healers and diviners, who employ their powers in the aid of others. Witches, as a genderless term, are however unambiguously evil. In the words and views of all respondents, when we speak of witchcraft and witches, we speak of those who aim only to destroy.

Beginning from the understanding of witchcraft as an act of harm and the witch as "an archetype of evil, an antisocial menace who betrays the bonds and the values of the community" (Bever 2000: 575), it is not immediately clear what the scope of this nefarious act entails. To begin, witchcraft cannot be described as a superstition, as it is not a unitary assumption of causality, such as walking under a ladder causing bad luck. Witchcraft is much more comprehensive, relating to human actions, intentions and experiences of the world. Thus witchcraft is a reality (Amadou 2010), part of the world that actually exists, is experienced and, though not seen, is evidenced in its outcomes. Witchcraft must therefore be understood as an aspect of the daily lives of people which looms behind every subject (Amadou 2010). The manifestations of this reality vary greatly and are often open to the interpretation of the individuals experiencing or witnessing them. However, there are many ideas regarding witchcraft which are widely held and shared.

Though witches have the power, individually and collectively, to create significant destruction, the primary targets of witchcraft attack are those who are closest to the witch: the immediate family. In witchcraft, there are no rules of engagement: parents may kill children, one another, or extended family members. The same is understood for children, who may attack their parents, siblings or relatives. Intimacy, in this reality, is the greatest risk, as the witch is able to harm those closest to them with the greatest effect. This idea of vulnerability to those with whom one lives is easily understood: the people we are closest to know us best and from this, know best how to harm us. This is also the ultimate betrayal as we invest the highest levels of trust to those in our lives, making their offences against us all the more unforgivable. In this respect, witches are the purest manifestation of the anti-social, they are that which makes all communality suspect, 
uncertain and unsettled. In addition to the direct harms of death, illness and misfortune they may bestow (Amadou 2010), witches upset the very idea of society, sowing seeds of disorder and distrust.

Though witch is often thought to refer to women in particular, there is no inherent gender of witchcraft. Some respondents felt that witches were more commonly women. However, when asked to clarify, this view was often supplemented by the caveat that women are more often victims of accusations, thus more frequently associated with witchcraft. Though some individuals did argue that women are predisposed to seek and engage in witchcraft this was not a consistent view.

Sanctions against witches have varied over time and are often seen to correspond to the sense of anxiety regarding the threat of witchcraft or the severity of the offence committed. Rehabilitation is possible, and in Ghana in particular, religious organizations and traditional authorities are seen to be responsible for this process. Witches may be absolved through confession, cleansing ceremonies or ordeals so long as the witch is devoted to living in the visible world. In churches, witches may repent and accept Jesus as their saviour and be delivered or exorcised of their witchcraft powers. In both instances, witches who betray their promise and seek to return to the invisible world will die immediately as a result. This is an implicit condition of rehabilitation. In some cases where witches do not die spontaneously, it also understood that it is acceptable for the individuals to ensure that the witch is put to death to ensure that further harm is prevented.

The killing of accused witches is quite prominent in Ghana. Accused witches are frequently subjected to ridicule, ostracism, assault and torture, exile and murder. The property of an accused witch may be seized by family members and social privileges such as access to communal foods, water and land may be limited. As there are no formal means for addressing witchcraft attacks or suspicions, the progression of suspicion to accusation is often rapid and severe. These murders are also highly visible within society. Reports and accounts of murdered witches are common in Ghanaian media and frequently recounted by individuals.

I had begun with the assumption that witchcraft-related violence would include accusations, ritual murder, and departing with the broad majority of academic texts, the use of witchcraft to attack another. Therefore, I chose to include supernatural violence in my working definition. I was not long in the field before it became clear that there are two understandings of witchcraft-related violence: attacks against accused witches and attacks by witches against people.

In respect to the first aspect, attacks against accused witches, it was clear that respondents were using this connotation of the term with me in recognition of my being Western. In discussion, violence was rarely used between respondents to describe attacks on accused witches. For example, in a group discussion in Ghana, two men discussed their part in having to put an accused witch to death without referring to violence or force at all. 
Instead, the two men recounted that after a mutual friend dreamt of a female neighbour biting him on the arm and woke to find teeth marks in his flesh, they confronted the woman and demanded a confession. In their retelling, the woman refused to confess and confronted with the evidence of the teeth marks they were compelled to "deal with" the woman, in this instance through lynching, a term connoting wider participation and invoking ideals of mob justice.

Though this story involved multiple acts of violence, the group reacted most strongly to the account of the dream and the detail of the bite marks on the man's arm. These experiences of spiritual violence, psychic attack in dream and spiritual attacks to the body and person, reflect a deep and pervasive insecurity in Ghana; one that is often overlooked. It is important to address why witchcraft attack is rarely defined in Western literature as a form of violence. The most obvious reason for this is the immediate rejection of witchcraft attack as an experience altogether. Though significant works have been written and entire theories developed around ideas of symbolic, institutional or structural violence, the question of invisible violence remains largely unexplored (Riches 1991). However, it is nonetheless the case that for those who participated in this research, witchcraft is a form of physical, as much as it is metaphysical, harm.

In pre-colonial times redressing supernatural violence was the responsibility of traditional authorities, who were empowered to judge accusations and mete out punishments to the accusers or accused. Penalties ranged from fines to exile or death. During the colonial period, many European administrators sought to eliminate witchcraft trials and colonial powers officially outlawed all witchcraft-related practices, including those intended to mediate violence or provide protection, such as healing and divination. The British Witchcraft Ordinance laws ${ }^{3}$ led to increased anxiety as people found themselves without spiritual protection amid an atmosphere of state scepticism in which witches were able to operate and proliferate without limitation. As a result, in the colonial and post-colonial periods, witchcraftrelated violence was seen as increasing and the frequency of witch hunts as escalating. Unfortunately, it remains difficult to judge the veracity of this perception as instances of witchcraft-related violence have not been consistently defined or measured over time.

The problem of witchcraft-related violence, understood as the continuing or increasing instance of witches attacking individuals is not without debate, as one fetish priest argued that there is no problem, except for the problem of people not knowing how to approach and be with witches and work with them for their mutual protection and benefit. Additionally, the perceived rise in witchcraft-related violence must also be considered in relation to the

3. These laws were officially instituted as The Gold Coast Native Jurisdiction Ordinance, 1910. 
conception of the phenomenon both as an illegal act and as an act of violence, two conditions which are relatively recent in comparison to reality of witchcraft itself.

An aspect of witchcraft-related violence which is difficult to measure is the assumed gendered nature of the phenomenon. Here it is important to keep in mind the differentiation between suspicion, accusations and violence, as well as the distinction between the two definitions of violence as attacks against witches and attacks by witches. In my research, I did not begin with the assumption that witchcraft itself is gendered and in my analysis this view was confirmed by interviewees and informants understandings, experiences and descriptions of witchcraft and witchcraft-related violence. The key point of disagreement that I have with interpreting witchcraft as gendered (Badoe 2005; Badstuebner 2003; Federici 2008; Houde 2010) is that this conceptualization negates witchcraft as it exists in reality, by denying that every individual is equally capable of drawing on supernatural power against any other individual, regardless of sex or gender. More problematically, as a political scientist, I am concerned by the placing of blame on witchcraft belief, which is almost always viewed sceptically, and thereby obfuscating what I see to be more fundamental cause of gendered violence surrounding witchcraft: the gendered power relations which exist within societies and through which witchcraft belief is enacted. In short, it is not witchcraft belief that is gendered, but rather, the societies which enact violence (of all kinds) against one sex more frequently than another.

It is as a result of gendered relations, not witchcraft, that women may be more vulnerable to witchcraft-related violence in the form of accusations than men. While the gendered character of accusations in some societies is an important characteristics of witchcraft-related violence, it is not a defining one. When witchcraft is understood as causing harm to another through supernatural means, there is no specific or inherent gender dimension therein. However, feminist works which have looked at witchcraftrelated violence have prioritized accusations and few have sought to define witchcraft, as it is often assumed to be a false belief, at best, or an expression of false consciousness at its worst. As a result of these biases, some feminist analyses of witchcraft-related violence have produced calls to action that may be more harmful than helpful (Badoe 2005; Federici 2008).

\section{The Modern State}

The question of whether the modern liberal state is able to reconcile with or incorporate the supernatural has been posed by a number of authors (Diwan 2004; Hund 2004; Geschiere 2006). Most prominently, the judicial systems of African states have been investigated for their effectiveness in trying individuals who have attacked or killed accused witches in South Africa (Ashforth 2005; Hund 2004), Tanzania (Mesaki 2009) and Zimbabwe 
(Diwan 2004). As well, the role of law enforcement officials has been addressed in South Africa, stressing the ambiguous position of officers who experience spiritual insecurity that is directly in conflict with their duties according to the law (Ashforth 2005; Ralushai et al. 1996).

To date, it seems that the results from these anthropological and legal studies are relatively consistent. The state is not only poorly equipped to appropriately address witchcraft belief and insecurity, it is also subject to the suspicions and insecurity which engagement with witchcraft discourse necessarily entails. Ironically, it is the power of the state to act which robs it of its legitimacy in acting. As many state leaders are themselves suspected of involvement in witchcraft practices, their efforts to implement legal protections against witch killings further undermines the construction of the state as an institution committed to protecting societies.

Ghana is fitting example of these findings. When the Ghanaian state addresses the issue of witchcraft-related violence, officials tend to focus on the witch camps in the Northern Region. This emphasis is the result of international attention and intense pressure by international non-governmental organizations calling on the state to address this phenomenon, which has received a disproportionate amount of press. As witch camps exist in other countries and are only one manifestation of witchcraft-related violence, their prominence in the global imagination of witchcraft and Africa is notable, and the Ghanaian state has responded the international pressure which has resulted from this attention. The government has declared its intention to close the witch camps, conceding to the criticisms that they violate human rights standards.

The government of Ghana officially condemns the existence of the witch camps but rarely addresses the issue of witchcraft belief or violence directly. Instead, modern liberal terms are employed, highlighting the conflict between the human rights of the accused and the criminal natures of offences, and the state's obligation to respect and difficulty in dealing with cultural practices. Often, the Northern region is referred to as being of another culture than the state, where traditional practices are maintained by societies which have yet to modernize, particularly in terms of wealth, education and social norms. By focusing on the witch camp phenomenon, state officials downplay important features of witchcraft-related violence which occur outside of the camps and reinforce international and national perceptions of the North as an impoverished, underdeveloped and under-resourced region.

The state encounters witchcraft-related violence most publicly and probably most frequently through the Commission for Human Rights and Administrative Justice. Known by its acronym, CHRAJ, the Commission was established in 1993 with the intention to "protect fundamental human rights and ensure good governance" (CHRAJ 2013). CHRAJ ${ }^{4}$ considers itself to be at the forefront of the witchcraft problem and credits itself for having brought

4. Ghana, State Official, 09/10/2012. 
the issue to the level of popular debate in Ghana. In its work investigating cultural practices which harm older women, CHRAJ identified witchcraft as a primary concern. CHRAJ and the Ministry of Women and Children's Affairs (MOWAC), identified culture as the most significant barrier to addressing witchcraft-related violence. Therefore working with communities to address this cultural problem is a stated priority of many government institutions (Peacefmonline 2013).

CHRAJ has suggested that the government commission an official investigation into the phenomenon and attempt to assess what witchcraft is, why there are witch camps in the North but not elsewhere, and what can be done to improve the situation. In its time working on the issue, CHRAJ has found that its own information on the subject is incomplete and its education efforts, rather than reducing instances, have seen an increase in cases. This is blamed in part on international factors, in particular accused witches entering Ghana from Togo and the failure of people to abandon their fears and accept the enlightened messages against witchcraft belief.

Other state officials have differing views on the role of the legal apparatus in addressing witchcraft-related violence. While government employees publicly declare their disapproval of accusations, including the abuses found in some spiritual churches and traditional practices, views on how to address this issue differ. The question of whether or not witchcraft is real and the governments official refusal to address witchcraft directly, looking instead at acts perpetrated in terms of law, led a number of interviewees to express the opinion that the state is failing in this area.

A fundamental concern, unaddressed by the state but questioned by officials, is how people come to be witches in the first place. A common response in interviews was that people desire advancement yet are unwilling to work towards this goal, seeking shortcuts through the invisible world.

The egalitarian nature of witchcraft as a form power is most apparent here. In a society, people are thought to have relatively equal access and ability; given their personal motivations individuals are able to build their lives while contributing to a collective good. Any person, regardless of age or sex, could seek to employ supernatural powers in order to advance themselves though most do not because of moral constraint: it is immoral to sacrifice another for ones benefit.

Those who do employ the supernatural for their own benefit, gain an unnatural advantage that costs not only the life of another person, but also their own humanity ${ }^{5}$. Witchcraft is therefore an immoral power, an antisocial and selfish threat to the collective good. It is commonly acknowledged in Ghana that politicians and civil servants are not exempt from this temptation (Ellis \& ter Haar 2004). It is also perceived by some that politicians and civil servants also seek to protect fellow witches, hence the inefficacy of state mediation (ibid.). Though many may be educated and may

5. Ghana, Fieldnotes 20/09/2012. 
condemn the actions of traditional authorities, state actors remain vulnerable to the same threat of witchcraft attack and may even advance accusations or bring their concerns to traditional authorities.

Traditional authorities are able to see the invisible world of witches and those who are able to work against witchcraft power do so to benefit others, often at considerable risk to themselves. Through this social service, the immoral aspect of supernatural power is diminished, thereby allowing the special place in society given to traditional authorities. The root of this conundrum is not lost on state officials who are themselves aware that traditional authorities gain legitimacy through the perception that their power comes from the invisible world. Therefore the opinions expressed by state officials must be considered, in part, as an endorsement of state power. Until people begin to critically question their own perceptions of power, witchcraft and reality, the question of how to resolve these conflicts will remain unanswered. However, in the mean time, officials agree that the issue of maltreatment must be dealt with, and in this respect the police are seen to be at the front-line.

Efforts by the state to appeal to people's sense of justice were also dismissed by respondents. Because Ghanaian courts will not hear cases of witchcraft attack, only the crime of accusation, the courts are seen as being unwilling or incapable of dealing with important spiritual matters. That individuals must suffer personal loss through witchcraft attack without any formal recourse led some respondents to express disappointment with the state. Police forces are also included in this dissatisfaction as respondents, in particular traditional healers, are aware that police procedures are lengthy and slow. According to some respondents ${ }^{6}$, this is a strong motivator for individuals to seek the services of traditional authorities.

As noted earlier, in conversation with Ghanaians and in media, it appears to be common knowledge that state officials participate in witchcraft and therefore the state has less incentive to effectively address the problem. Here, the logic trap of witchcraft becomes apparent. The state is empowered by the supernatural, therefore it cannot act against witchcraft honestly or effectively, to do so would be to diminish the power of the state.

When respondents spoke about how to effectively address the problem of witchcraft-related violence, answers were sometimes confused, conflicting and uncertain, even within the replies of individual respondents. The main focus of these exchanges often addressed the witch camps in the north. Many respondents felt that accused witches would be incapable of escaping the stigma of their accusation anywhere in the country, while some expressed concern for those who may be falsely accused but who would internalize

6. Ghana, Non-Governmental Organization 23/10/12; Traditional Authority 20/09/12; State Official 09/10/12. 
these accusations. One informant ${ }^{7}$ correlated stigma and shame with the necessity of ensuring one contributes positively to society in order to avoid back biting or gossip which may lead to accusations.

Another respondent, a chief ${ }^{8}$, stressed the need for people to feel protected and for a spiritual solution to the problem. For him, the closing of the camps would only be possible if the government supported traditional authorities. This collaboration would involve the government financing education and funding traditional authorities who are willing to accept responsibility for the safety of accused witches so long as they do not try to teach others witchcraft.

Many respondents also voiced concern that though there is a tendency to view witchcraft as a source of misfortune, it is necessary to be certain that an accused is truly responsible. For many respondents, there is inadequate effort to determined the veracity of an accusation. Therefore, many respondents felt that witches who had not been convincingly determined to be guilty, by supernatural or other means, are being treated unjustly. If the accused are not witches, then they should be freed from the camps or provided for by the government until they are able to find a safe home. However, whether or not it is the governments responsibility to determine whether an accused is in fact a witch again presents a conflict. Respondents noted that the state should resolve accusations in court, but as they cannot include traditional authorities in the process, they remain incapable of determining an accused status. Thus the state remains in conflict with spiritual powers which it cannot officially possess.

\section{Non Governmental Organizations}

NGOs are often viewed with mixed feelings in Ghana. Though NGOs are an established part of the political landscape concerns remain that NGOs are a continued form of foreign control. This concern was voiced by respondents who made a strong distinction between local and foreign NGOs, though the differentiation is somewhat problematic, as the NGO model itself is foreign and many organizations which are thought to be local, such as HelpAge Ghana, the Presbyterian go Home Project, and ActionAid, are local subsidiaries of larger international organizations.

Hostility towards intervention by the West, particularly in respect to witchcraft, was a persistent subtext in discussions during my field research. Concern about foreign NGOS was most succinctly expressed by one informant who cautioned that NGOs that come from different cultures and attempt to see things in their own way would fail in their interventions. This conclusion, that NGOs are incapable of overcoming their biases to effectively aid

7. Ghana, Fieldnotes 15/09/12.

8. Ghana, Traditional Authority, 18/09/2012. 
Ghanaians, was also shared by a chief ${ }^{9}$ who expressed frustration with the human rights discourse of NGOs. Though he acknowledged that human rights are a good idea, it was much more important to find out why witchcraftrelated violence was occurring. Because NGOs lacked a foundational knowledge of people's concerns, the chief argued, people tend to dismiss human rights as irrelevant. In place of co-option, the chief felt that consultation with traditional authorities and elders would be more successful in solving the problem of witchcraft-related violence.

In interviews, representatives of religious institutions were much more supportive of NGOS and their work to address witchcraft-related violence than other respondents. In particular, one religious leader stressed the role of NGOs in reducing witchcraft belief and changing cultural practices through advocacy efforts and education, including the harmful work of some deliverance churches. The emphasis on education was a common theme, in particular for one religious leader ${ }^{10}$ who noted that a central success of NGO education efforts was to reduce belief in witchcraft, which complemented the work by churches to replace this belief with a strong belief in God.

Though respondents generally expressed support for the intentions of NGOs to improve the living conditions of accused witches, they were unconvinced that NGOs would be able to successfully address the underlying factors involved, such as continued belief in witchcraft, recurring violence and the insecurity experienced in society. Respondents overwhelmingly felt, as one state representative ${ }^{11}$ noted, that NGOs were seeking short-term solutions for a long-term problem, one which has been part of their society for centuries.

In interviews with ActionAid Ghana, the Gambaga Outreach (go) Home ${ }^{12}$ and HelpAge Ghana ${ }^{13}$, there was a clear awareness of the complexity of the situation of witchcraft-related violence. All three NGOs expressed concerns that the state and traditional authorities also have significant roles to play in reducing instances of witchcraft-related violence. In particular, ActionAid Ghana expressed that the state is primarily responsible for ensuring that the witch camps in the Northern Region are closed.

This emphasis on the role of the state and the prominence of human rights discourse defines the approach of ActionAid and distances this organization from other NGOs addressing the issue of witchcraft in Ghana. ActionAid, to a greater extent than HelpAge Ghana and the go Home Project, draws upon the logic of the liberal state in expressing the view that the government is foremost responsible for the protection of accused women, the prevention of additional women being sent to them, and ensuring that the camps are closed permanently.

9. Ghana, Traditional Authority, 17/09/2012.

10. Ghana, Religious Organization, 28/09/2012.

11. Ghana, State Official, 23/10/2012.

12. Ghana, Non-Governmental Organization, 09/10/2012.

13. Ghana, Non-Governmental Organization, 23/10/2012. 
Whereas HelpAge Ghana and go Home Project seek broader social collaboration in the mediation of witchcraft-related violence, ActionAid strongly believes that CHRAJ and MOWAC are uniquely responsible for sensitizing the population regarding their legal rights as citizens and in enforcing laws against violence by bringing culprits before courts. This approach strongly reflects the international origins of the organization, drawing on the legal responsibilities of the state to the individual. ActionAid also echoed concepts of the Western welfare state in interviews, noting that the provision of social goods and services is a responsibility that belongs in the hands of the state, not NGOs.

Again, unlike HelpAge Ghana and the go Home Project, ActionAid draws on the assumed relations of the state and individual in their mobilization campaigns. As noted by one respondent, ActionAid has successfully mobilized accused women in the witch camps to sign petitions and stage marches in protest against government inaction, initiatives which reflect a concept of state-society relation grounded in the liberal social contract. Where ActionAid seeks to engage the state as the primary solution to witchcraftrelated violence, HelpAge Ghana and go Home take a remarkably different approach. In interviews, both HelpAge Ghana and go Home expressed concern that the issue of witchcraft-related violence is misrepresented, is in fact much more limited and cannot be widely applied to Ghana.

Both HelpAge Ghana and the go Home project acknowledge the existence of witchcraft and witchcraft-related violence, however, each organizations suggests that the problem is not as serious as many believe. HelpAge Ghana presents a middle ground between Action Aid and go Home, suggesting that while violence is unnecessary in dealing with accused witches, state involvement is sometimes required where violence does occur, as the law does provide protection from libel and abuse and secures the rights of Ghanaians to be free from accusation. In regard to witchcraft, HelpAge acknowledges its existence and notes that witchcraft itself is not illegal in Ghana and were it to be banned, the act itself cannot be proven. Similarly, go Home Project, witchcraft-related violence cannot be addressed as a human rights issue because the question of justice is not unidirectional, where the accused alone is suffering injustice. Contrary to the approach of the government which emphasizes the human rights abuses of the accused as injustice, villages and families are recognized as enacting a socially accepted form of justice by banishing accused witches.

Rather than focusing on accusations, go Home works with accused women and their villages to achieve reconciliation and to make peace between or within families. In go Home's reintegration efforts, the role of traditional authorities is central and chiefs are consulted before any other village resident or family member. In addition to their influence on public opinion, the willingness of a chief to accept the return of an accused witch is considered to be a guarantee that the woman will not be harmed once she returns 
to the village, though all returned women are also visited regularly to ensure their continued safety.

The fundamental belief motivating these organizations approaches to witchcraft-related violence underlines the ambiguity of witchcraft power. Both HelpAge Ghana and the go Home Project respondents stressed in interviews and in discussion that witchcraft is not uniquely evil, but may also be used to heal and protect. Though fear of witchcraft attacks remains a part of many people's daily life (the personal experiences of staff members at HelpAge Ghana confirm the immensity of this threat), it is important to recognize witchcraft and witches as a potential benefit to society, depending on how the power is employed by the individual witch.

The view expressed by HelpAge, that spiritual power, whether harmful witchcraft or protective sorcery, is an individual responsibility and must be managed by the individual, closely reflects the views of informants who were themselves victims of witchcraft violence as well as some religious leaders. Though this is a minority view, it is one that must be distinguished from the dominant discourse of witchcraft as purely evil. While all informants stressed that witches are spoken of as being evil, and therefore defined (in part by international discourse) as evil, this is not necessarily the case. One informant ${ }^{14}$, who comes from a family of witches and whose mother was exiled to a witch camp, expressed this view most emphatically. For the informant, witchcraft power is not inherently negative, rather it is a source of power that can be helpful, providing healing where modern medicine cannot, good fortune and protection for families and friends of witches. Conflict arises when witches have accidents, such as falling from flight into a strangers home, rather than as the result of malicious attack. Thus, the solution to witchcraft-related violence is not greater intervention, but greater communication and willingness to co-exist peacefully with witches ${ }^{15}$.

\section{Religious Organizations}

The belief that religion is at odds with traditional practices was most commonly expressed by traditional authorities. One traditional healer ${ }^{16}$ argued that between the two ways, traditional and religious, the traditional way is stronger though more perilous because by working through the supernatural, traditional healers are also at risk of attack by nefarious spirits. A number of chiefs expressed strong views in support of traditional practices as well, with one ${ }^{17}$ suggesting that the work of churches to address witchcraft-related violence will not succeed until pastors consult traditional spiritual powers.

14. Ghana, Victim of Witchcraft, 25/09/2012.

15. Ghana, Non-Governmental Organization, 09/10/2012; Ghana, Non-Governmental Organization, 23/10/2012; Ghana, Victim of Witchcraft, 25/09/2012.

16. Ghana, Traditional Authority, 18/09/2012.

17. Ghana, Traditional Authority, 17/09/2012. 
One chief ${ }^{18}$ noted that pastors speak of God but witches do not know God. Therefore religion is unable to act alone and though "religion talks, people don't mind". Traditional authorities who were supportive of the religious organizations were often themselves self-identified Christian or felt that the work of religious organizations in identifying and exorcising witchcraft spirits was a positive contribution to the overall effort to address the witchcraft systems.

Churches themselves expressed varying views towards their relationship to witchcraft and witchcraft-related violence. In the Presbyterian Church $^{19}$, witchcraft is acknowledged as a social belief. However it is abhorred because it fails to contribute to the progress of society and magic is forbidden when it is for non-progressive ends. In this, the Presbyterian church expresses much of the ambiguity commonly applied to witchcraft. Though the Church has worked to address the needs of accused witches, it nonetheless remains convinced of the existence of witchcraft, sometimes as a social phenomenon and sometimes as real spiritual tool or threat.

Witchcraft fears are also seen as having corrupted some Christians churches, particularly those who use exorcism as a means to impress people and draw them to their congregation. For the Presbyterian church, the use of deliverance to attract converts not only contributes to witchcraft fears, it also creates opportunities for violence and excessive abuses, such as chaining people who are suffering from physical or psychological illnesses. Though the work of deliverance centres is often framed as false or manipulative, the Presbyterian church noted that in the Ghanaian context, where syncretism is the norm, some pastors also believe in these traditional practices.

For respondent ${ }^{20}$ from the Catholic church, witchcraft is a known phenomenon which is believed to be part of God's creation. However the church does not view the witch as an actor of evil but rather as a human being who is doing something evil with a God-given talent that is meant to be used for good. In terms of witchcraft-related violence, one priest expressed the view that violence is understood as witchcraft attack and must be taken seriously. As the church is seen as being unable to address witchcraftrelated violence alone, the government, which "has the upper hand", was identified as the responsible actor for supporting the church. However, the government is slow to act because they are assumed to be in contact with and assisted by witches who are preventing the state from employing witchcraft for good as was accomplished in Europe (leading to advancement and modernity).

In the Pentecostal faith, all that is required for protection is the name of Jesus, which witches are unable to stand against. For the church, the government is responsible for leading initiatives against violence, though

18. Ghana, Traditional Authority, 17/09/2012.

19. Ghana, Religious Organization, 25/09/2012.

20. Ghana, Religious Organization, 27/09/2012. 
some may be ineffective as the government is viewed as being ignorant to the needs of people. NGOs are seen as being responsible for sensitization, though no description of this was provided. Traditional authorities are those who are most at odds with the church and its efforts to combat witchcraft. Here the problem of syncretism was raised as the permissive cause of significant abuses by traditional authorities, including sexual slavery though trokosi and human trafficking, which employs rituals using women and girls' hair or blood to enforce their silence under penalty of death. In addressing these issues, the pastor requested that I make very clear in my research that the government is not the answer, nor NGOs, but that only the word of God and the power of the gospel can deal decisively with witchcraft. As evidence of this, the pastor noted the historical success of the church in the 1930s and 1940s in eliminating the anti-witch cult Tigare.

Though the power of God is widely endorsed, the question of how God acts in our world is complicated by the human intermediary. As a result, religious intervention becomes highly political and power may be exercised and abused to the detriment of others. This difficult dimension was succinctly addressed on a larger scale by an NGO worker in the story of a village where, according to the respondent, people had never heard of witchcraft. It was not until new churches arrived (the village had been predominantly Presbyterian before this) that accusations of witchcraft began and families turned on one another.

\section{Traditional Authorities}

There is a long history of centralized power in many parts of Ghana (the north is an exception), where kings and chiefs were well established before colonization and where many kingdoms remain relevant actors in local governance, continue to inform individuals identities and are deeply connected to the invisible world. Despite constitutional limitations on their power, chiefs remain potent actors and continue to wield authority outside of the states control or ability.

The view that these powers are not only legitimate but also relevant to the mediation of witchcraft was consistently expressed in interviews. Though there was a small number of respondents who expressed both support and caution towards the role of traditional authorities, implicating chiefs as well as healers, diviners and priests, the majority of responses expressed the opinion that they are the most important actors in addressing witchcraftrelated violence.

According to one state official ${ }^{21}$, traditional authorities are key to addressing witchcraft-related violence because they appeal to the belief in witchcraft itself. The official felt that traditional authorities, as custodians

21. Ghana, State official, 23/10/2012. 
of the community, should be working to reintegrate accused witches. However, the official noted that chiefs are not able to take accused witches into their own homes, therefore safe havens (i.e. witch camps) must be established so that the accused may remain in the community while the process of reintegration unfolds.

The views expressed by chiefs were somewhat surprising in their disinterest or dismissal of witchcraft as a pressing concern and the chiefs themselves did not express the same sense of responsibility shared by other informants and respondents. A chief ${ }^{22}$ interviewed in Greater Accra referred to witchcraft as a chewing stick, the subject of much discussion but little import, and rejected the conceptualization of witchcraft as a problem. Rather, what was problematic for the chief was the refusal of individuals to allow traditional interventions to proceed because family members were contesting the validity of the accusations, and by extension, the authority of the community.

As another chief ${ }^{23}$ explained, Ghanaians believe that chiefs are spiritual, however, not all chiefs possess the ability to mediate the supernatural. While some chiefs are natural doctors (healers) or diviners, even their rulings on witchcraft may be disregarded as inconclusive and people may demand the intervention of a fetish priest or prophet (elder who sees spiritually) in order to confirm the chief's judgement. The intervention of the chief separated from the support of spiritual actors becomes much more mundane and practical. What is of greater importance is the chiefs role in protecting the community. One respondent ${ }^{24}$ who is positioned to succeed the current chief of Tamale emphasized the role of chiefs in ensuring that accused witches and their families, particularly those in the camps, are not subjected to physical attacks. Instead of ruling on the supernatural aspects, chiefs are responsible for the securing the physical safety of individuals and the hearing of grievances in order to de-escalate conflicts through mediation.

Possession of supernatural power and access to the invisible world, even in cases where this is seen to be beneficial, exposes a spiritual person to the potential of suspicion and accusation. For respondents who cautioned that while traditional authorities are central to addressing witchcraft-related violence there remained a concern that the same power which enables their efficacy may also pose a risk. The uncertain allegiance of traditional authorities, who may have one foot in the visible world and another in the invisible, is the cause of considerable doubt. One state official ${ }^{25}$ addressed this ambiguity directly, questioning where these actors should contribute to the effort to reduce witchcraft-related violence. The official saw a clear dilemma for traditional authorities who are empowered by beliefs and practices which

22. Ghana, Traditional Authority, 24/09/2012.

23. Ghana, Traditional Authority, 29/09/2012.

24. Ghana, Traditional Authority, 07/09/2012.

25. Ghana, State Official, 23/10/2012. 
are not reflected in the modern state and state institutions. The crux of this conflict was articulated through the ideals of enlightenment and education; chiefs and healers as educated individuals should draw on reason and rationality and therefore reject the very notion of witchcraft. However by the virtue of their own positions in society, as representatives of deities, ancestors or the supernatural, their power is in the invisible world, forcing them to confront and acknowledge the existence of witchcraft.

Another chief ${ }^{26}$ argued that chiefs in Ghana do not have mystical power. They are supposed to, but in practice it is an individual choice whether or not to attain juju (spiritual power). However, in the city of Kumasi a chief may be chosen to be the nsumakwa-hene, to be a spiritual chief who knows all about witchcraft. In these cases, the supernatural powers of these chiefs are endorsed as a positive form of witchcraft and who specialize in witchcraft mediation. However, unlike chiefs, there are few clear social norms which regulate the activities of healers and diviners. Rather than being institutions of social and political organization, healers and diviners are independent, their knowledge is hidden and their workings are revealed only to those they treat, and even such in cases, only the rituals and substances employed may be seen. The invisible workings of a healers or diviners power remains inaccessible and uncertain. As one traditional healer ${ }^{27}$ noted, he has the power to help people, make them bulletproof, calm their minds of worry or protect them in their life, he may even know when a request is genuinely needed or not, but he cannot reveal how he knows or accomplishes these things. Only a spiritual person may know how the spiritual world works in the visible.

Witchcraft-related violence in Ghana is commonly perceived as a serious and persistent phenomenon. However, the problem of witchcraft is much more complex than typically depicted in media. Witchcraft presents a profound insecurity that forms and informs all aspects of one's life, affecting social and political relations in society. Understanding witchcraft as a form of power and looking at this very real sense of insecurity exposes important critiques in Ghanaian society, including ideas of what power is, where power comes from and who is most responsible for managing illegitimate or immoral uses of this power.

In Ghana, the state relies on Western institutional power, which is based a legal-rational liberal logic and therefore unable to address witchcraft or spiritual power. Despite this foundation, the state is also spiritualized through an association with witchcraft. When the state attempts to act outside of

26. Ghana, Traditional Authority, 29/10/2012.

27. Ghana, Traditional Authority, 17/09/2012. 
this association, its continues to lose legitimacy. The state, therefore, finds itself in a no-win situation. Similarly, NGOs may rely on foreign conceptions of human rights, education and reality that alienate people by perpetuating insecurity. Like the state, NGOs are themselves unable to escape the conflict they create between modernity (human rights, development, education) and witchcraft. Where NGOs conform to witchcraft reality, in response to the local beliefs of the NGO staff and members or in order to access and legitimately within this reality, they risk compromising their national and international status in relation to the state as they are, in essence, alienating themselves from modernity.

Though many people who believe in witchcraft seek protection from religious organizations, even the power of God is insufficient to prevent the permeation of witchcraft. Religious organizations, in particular Pentecostalism, are able to exploit this insecurity through interventions and mediation efforts which claim to provide protection but which also bring additional financial and political benefits. Ultimately, traditional authorities, which rely on the same spiritual power as witches, are seen to be pivotal actors in addressing witchcraft violence. Unfortunately, these actors are also mired in the same ambiguities as other spiritual actors, leading to significant ambivalence regarding this role. Additionally, these actors also face continuing pressure to sever these spiritual ties and formally bind themselves to the concepts of power advanced by the institutional state system.

Despite these conflicts and limitations, Ghana is in an ideal position to address witchcraft-related violence. While Ghana is subject to disproportionate international attention leading to the perception that witchcraftrelated violence is both prevalent and increasing, Ghanaians benefit from a high level of openness and active social debate regarding witchcraft. Daily reports of witchcraft violence in the news and media and discussions regarding the future of the witch camps in the north continue to promote popular engagement, reflection and discussion. Though there is no simple solution to such as complex issue as witchcraft, there is significant opportunity in Ghana for people to participate actively and assertively in shaping their world and reality.

Therefore, despite the global dominance of the state and modernity, their position remains uncertain. Though modernity has had considerable success in altering the landscape of African realities, the century long effort to erase witchcraft belief from the imagined and lived terrain of African peoples continues. Instead of falling away into the realm of forgotten tradition, witches are more powerful than ever. Until people are able to regain their ability to effectively and consensually govern their supernatural reality, witchcraft will continue to resist domination and frustrate the ability of hegemonizing logics to redefine both imagination and reality in African societies. 


\section{BIBLIOGRAPHY}

Adjaye, J. K. \& Misawa, B.

2006 "Chieftaincy at the Confluence of Tradition and Modernity: Transforming African Rulership in Ghana and Nigeria", International Third World Studies Journal and Review 17: 1-10.

Ae-Ngibise, K., Cooper, S., Adimokah, E., Akpalu, B., Lund, C., Doku, V. \& The Mhapp Research Consortium

2010 "'Whether you like it or not people with mental problems are going to go to them': A Qualitative Exploration into the Widespread Use of Traditional and Faith Healers in the Provision of Mental Health Care in Ghana", International Review of Psychiatry 22 (6): 558-567.

Amadou, E.

2010 Le développement de l'Afrique à l'épreuve des réalités mystiques et de la sorcellerie (Paris: L'Harmattan).

AsHForth, A.

2005 Witchcraft, Violence and Democracy In South Africa (Chicago: University of Chicago Press).

Atiemo, A. O.

2006 "International Human Rights, Religious Pluralism and the Future of Chieftaincy in Ghana", Exchange 35 (4): 360-382.

BADOE, Y.

2005 "What Makes a Woman a Witch?", Feminist Africa 5: 37-51.

BADSTUEBNER, J.

2003 "'Drinking the Hot Blood of Humans': Witchcraft Confessions in South African Pentecostal Church", Anthropology and Humanism 28 (1): 8-22.

BEVER, E.

2000 "Witchcraft Fears and Psychosocial Factors in Disease", Journal of Interdisciplinary History 30 (4): 573-590.

BOAFO-ARTHUR, K.

2003 "Chieftaincy in Ghana: Challenges and Prospects in the $21^{\text {st }}$ Century", African and Asian Studies 2 (2): 125-153.

BONGMBA, E.

2001 African Witchcraft and Otherness: A Philosophical and Theological Critique of Intersubjective Relations (Albany: State University of New York Press).

BOTCHWAY, K.

2001 "Paradox of Empowerment: Reflections on a Case Study from Northern Ghana", World Development 29 (1): 135-153. 
Chabal, P.

2009 Africa: The Politics of Suffering and Smiling (London: Zed Books).

Commission on Human Rights and Administrative Justice (Chraj)

2013 "What We Do", Commission on Human Rights and Administrative Justice Ghana, <http://www.chrajghana.com/?page_id=27>.

Ciekawy, D. \& Geschiere, P.

1998 "Containing Witchcraft: Conflicting Scenarios in Postcolonial Africa", African Studies Review 41 (3): 1-14.

DEAN, J.

1998 Aliens in America: Conspiracy Cultures from Outerspace to Cyberspace (Ithaca: Cornell University Press).

DiWAN, M.

2004 "Conflict Between State Legal Norms and Norms Underlying Popular Beliefs: Witchcraft in Africa as a Case Study", Duke Journal of Comparative and International Law 14 (2): 351-387.

DRUCKER-BROWN, S.

1993 "Mamprusi Witchcraft, Subversion and Changing Gender Relations", Africa: Journal of the International African Institute 63 (4): 531-549.

Dzivenu, S.

2008 "The Politics of Inclusion and Exclusion of Traditional Authorities in Africa: Chiefs and Justice Administration in Botsawa and Ghana", Political Perspectives 2 (1): 1-30.

ELLIS, S. \& TER HAAR, G.

2004 Worlds of Power: Religious Thought and Political Practice in Africa (New York: Oxford University Press).

FEDERICI, S.

2008 "Witch-hunting, Globalization, and Feminist Solidarity in Africa Today", Journal of International Women's Studies 10 (1): 21-35.

Geschiere, P.

2006 "Witchcraft and the Limits of the Law: Cameroon and South Africa", in J. Comaroff \& J. Comaroff (eds.), Law and Disorder in the Postcolony (Chicago: University of Chicago Press): 219-246.

Horkheimer, M. \& Adorno, T. W.

2002 Dialectic of Enlightenment: Philosophical Fragments (E. Jephcott. Trans.) (Redwood City: Stanford University Press).

Houde, C.

2010 "The 'Witches' of Gambaga", in Progress \& Opportunities for Women's Equality Rights (POWER): Africa-Canada, Human Rights Research \& Education Centre (Ottawa: University of Ottawa): 1-31. 
Hund, J.

2004 "African Witchcraft and Western Law: Psychological and Cultural Issues", Journal of Contemporary Religion 19 (1): 67-84.

KOHNERT, D.

1996 "Magic and Witchcraft: Implications for Democratization and PovertyAlleviating Aid in Africa", World Development 24 (8): 1347-1355.

2003 "Witchcraft and Transnational Social Spaces: Witchcraft Violence, Reconciliation and Development in South Africa's Transition Process", Journal of Modern Africa Studies 41 (2): 1-29.

2007 "On the Renaissance of African Modes of Thought: The Example of Occult Belief Systems", MPRA Paper, 7019: 32-54, <http://mpra.ub.uni-muncher.de/ $7019 />$.

LABRANCHE, S.

2002 "Westernization of Political Legitimacy in Ghana through NGOs", The Review of International Affairs 2 (1): 80-99.

MesaKi, S.

2009 "Witchcraft and the law in Tanzania", International Journal of Sociology and Anthropology 1 (8): 132-138.

MEYER, B.

1998 "Make a Complete Break with the Past': Memory and Postcolonial Modernity in Ghanaian Pentecostal Discourse", in R. Werbner (ed.), Memory and the Post-colony: African Anthropology and the Critique of Power (London: Zed Books): 316-349.

ONYINAH, O.

2002 "Deliverance As a Way of Confronting Witchcraft in Modern Africa: Ghana As a Case History", Asian Journal of Pentecostal Studies 5 (1): 107-134.

\section{PEACEFMONLINE}

2013 'I Will Cater for 'Witches' and 'Kayeyei' - Oye Lithur', Peacefmonline, 31 January, <http://www.ghanaweb.com/GhanaHomePage/NewsArchive/ artikel.php?ID=263718>.

Porter, G.

2003 "NGOs and Poverty Reduction in a Globalizing World: Perspectives from Ghana", Progress in Development Studies 3 (2): 131-145.

RALUSHAI, V. ET AL.

1996 "Report of the Commission of Inquiry into Witchcraft Violence and Ritual Murders in the Northern Province of the Republic of South Africa", Commission of Inquiry into Witchcraft Violence and Ritual Murders, Ministry of Safety and Security (Northern Province, RSA).

ROXBURGH, S.

2014 Witchcraft, Violence and Mediation in Ghana: A Comparative Study of Ghana and Cameroon, Ph.D. Thesis, Ottawa, University of Ottawa, <https: //www.ruor.uottawa.ca/bitstream/10393/31641/1/Roxburgh_Shelagh_2014_ Thesis.pdf $>$. 
Riches, D.

1991 “Aggression, War, Violence: Space/Time and Paradigm”, Man 26 (2): 281-297.

Wendt, A. \& Duvall, R.

2008 "Sovereignty and the UFO", Political Theory 36 (4): 607-633.

West, H. G. \& SANDERs, T.

2003 Transparency and Conspiracy: Ethnographies of Suspicion in the New World Order (London: Duke University Press).

\section{ABSTRACT}

Witchcraft-related violence in West Africa is currently attracting significant international media attention. Often witchcraft-related violence is portrayed as a recent or increasing phenomenon, particularly in Ghana's Northern region where the infamous witch camps are located. These witch camps are often depicted as epitomizing violence against women and violence itself is characterized as the inevitable outcome of witchcraft belief. This paper problematizes this approach to witchcraft through an investigation of witchcraft as a complex, lived reality. Through this lens, the efforts of four institutions to mediate witchcraft in Ghana are assessed: the state, NGOs, religious organizations and traditional authorities. Based on interviews with these actors and victims of witchcraft-related violence, this paper highlights the fundamental epistemological conflict underlying contemporary interventions, which fail to address the spiritual insecurity that many Ghanaians experience on a daily basis.

\section{RÉSUMÉ}

La sorcellerie et la violence au Ghana. Une évaluation des efforts de médiation contemporaine. - La violence liée à la sorcellerie en Afrique de l'Ouest attire actuellement d'une façon importante l'attention des médias internationaux. Souvent, la violence liée à la sorcellerie est dépeinte comme un phénomène récent ou en voie de croissance, en particulier dans la région du nord du Ghana où se trouvent les camps de sorcières notoires. Ces camps de sorcières sont souvent dépeints comme symbolisant la violence contre les femmes, et la violence-même est caractérisée comme étant le résultat inévitable de la croyance en la sorcellerie. Cet article problématise cette approche de la sorcellerie par une enquête de celle-ci en tant que réalité vécue complexe. Dans cette optique, nous évaluons les efforts des quatre institutions qui intercèdent à la sorcellerie au Ghana: I'État, les ONG, les organisations religieuses et les autorités traditionnelles. En se basant sur des entretiens avec ces quatre acteurs, ainsi qu'avec des victimes de la violence liée à la sorcellerie, cet article met en évidence le conflit épistémologique qui sous-tend les interventions contemporaines, qui ne parviennent pas à répondre à l'insécurité spirituelle que nombreux Ghanéens ressentent de façon quotidienne.

Keywords/Mots-clés : Ghana, witchcraft, mediation and power, violence/Ghana, sorcellerie, médiation et pouvoir, violence. 